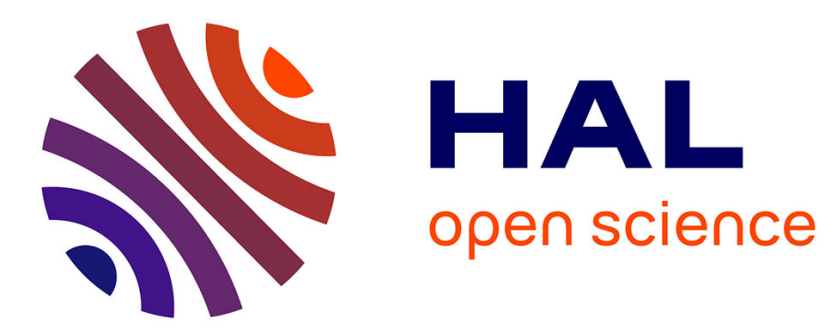

\title{
The effects at home of initiating production abroad: evidence from matched French firms
}

Alexander Hijzen, Sébastien Jean, Thierry Mayer

\section{To cite this version:}

Alexander Hijzen, Sébastien Jean, Thierry Mayer. The effects at home of initiating production abroad: evidence from matched French firms. Review of World Economics, 2011, 147 (3), pp.457483. 10.1007/s10290-011-0094-x . hal-00680707

\section{HAL Id: hal-00680707 https://hal.science/hal-00680707}

Submitted on 20 Mar 2012

HAL is a multi-disciplinary open access archive for the deposit and dissemination of scientific research documents, whether they are published or not. The documents may come from teaching and research institutions in France or abroad, or from public or private research centers.
L'archive ouverte pluridisciplinaire HAL, est destinée au dépôt et à la diffusion de documents scientifiques de niveau recherche, publiés ou non, émanant des établissements d'enseignement et de recherche français ou étrangers, des laboratoires publics ou privés. 


\title{
The Effects at Home of Initiating Production Abroad: Evidence from Matched French Firms
}

\author{
Alexander Hijzen \\ (OECD, Paris and GEP, University of Nottingham)
}

Sébastien Jean

(INRA, UMR 210 Economie publique, 16 rue Claude Bernard, 75231 Paris Cedex 05, France ; AgroParisTech, UMR 210 Economie publique ; and CEPII)

Thierry Mayer

(Sciences Po, CEPII and CEPR)

\begin{abstract}
Based on matching techniques in combination with a difference-in-difference estimator, this paper estimates the effects at home of initiating production abroad through the establishment of a foreign production affiliate. The analysis covers manufacturing and service firms active in France during the period 1987-1999. We show that the motivation to start producing abroad is an important determinant of its impact at home. Marketseeking foreign direct investment (FDI) in manufacturing is associated with significant scale effects, resulting in job creation. By contrast, factor-seeking FDI in manufacturing has no significant effect on employment. However, there is some evidence that this type of FDI is associated with technology effects, in the form of greater capital-intensity and efficiency, as well as larger exports. Finally, FDI in service sectors is associated with significant positive employment effects, presumably reflecting the importance of the market-seeking motive in these sectors.
\end{abstract}

Keywords: FDI, multinationals, propensity score matching, services, delocalisation.

JEL Code: F14, F21, F23

Correspondence: sebastien.jean (at) grignon.inra.fr (S. Jean) 


\section{Introduction}

Concerns are repeatedly expressed about the potential negative employment impact of the relocation of production abroad, often referred to as offshoring (see for instance Mankiw and Swagel 2006, for a discussion). Even though this issue has been subject to intense scrutiny for several years, it remains debated, with still widely varying conclusions found in the literature. Following Feenstra and Hanson (1999), several works have studied how foreign outsourcing, evaluated through direct or indirect measurements of imported intermediate inputs, affect labour demand (see e.g. Hijzen et al. 2005, Ekholm and Hakkala 2005, or Munch and Skaksen 2009). The results are mixed but point in several cases to a significant impact of outsourcing upon labour demand. Another approach relies on the estimation of multilocation cost functions by multinational enterprises (MNEs). Many of these studies conclude that the impact of foreign affiliates upon domestic employment is very limited, as for instance Slaughter (2000). However, following this approach, Mündler and Becker (2010) emphasize the need to take into account not only the intensive margin, as measured through employment changes in MNEs' different locations, but also the extensive margin, i.e. new location decisions. Their results suggest that MNEs operations abroad may have a non-trivial impact upon their employment at home.

Fears are heightened further by the recent feeling that service activities, often considered to be relatively skilled, are no longer invulnerable to the offshoring phenomenon (Blinder 2006). In this area, the evidence is scanter. While acknowledging the steady growth of service offshoring, Amiti and Wei (2005) show that it is not negatively related to sector-level employment growth in the United Kingdom; in the United States, a negative relationship can be found at a very detailed level, but it disappears when sectors are defined more broadly (Amiti and Wei 2008). While the influence of offshoring on labour productivity is noteworthy (Amiti and Wei 2009), these pieces of evidence suggest that the employment impact of services offshoring should remain limited - as also suggested by the fact that developed countries tend, more often than not, to run surpluses in trade in services. While these results are useful to clarify the orders of magnitude at stake, questions remain about the nature of the relationship between offshoring and labour demand. Focusing on the structure of labour demand, Crinò (2010) shows that offshoring increases employment in more skilled 
occupations, with potentially significant impact across labour categories. While anxiety surrounding services offshoring sometimes appear to have been exaggerated, the conclusions to be drawn from the existing literature remain contentious.

To shed further light on the economic consequences of offshoring, we focus here on a more specific question by asking how the decision to invest abroad influences firms' key outcomes at home, both in manufacturing and service sectors. We take advantage of this focus to cope with the well-known difficulty to separate out cause and effect in the specificities of foreign investors: the choice between investing or not investing for a firm in a certain industry largely results from a process of self-selection, as shown for instance by Helpman et al. (2004). Consequently, comparing firms that invest abroad to the average firm that does not do so would be misleading. Ideally, one would like to compare the outcome of firms that decided to become multinationals with the counterfactual outcome had those firms not decided to become multinationals, but this counterfactual outcome is unobservable. We address this concern by adopting matching techniques in combination with a difference-in-difference (DID) estimator. This allows one to evaluate the causal effect of establishing a foreign affiliate on a set of domestic firm-specific outcomes .

The causal effect of firm's global engagement strategies has received ample attention in the literature on exporting, ${ }^{1}$ but so far has received limited attention in the context of multinationals. Egger and Pfaffermayr (2003) use several different endogenous treatment approaches to analyse the impact of investing abroad on the domestic investment behaviour of Austrian manufacturing firms. Barba Navaretti and Castellani (2003) use propensity score matching to estimate the causal effect of investing abroad on the performance of Italian firms, as do Hijzen et al. (2007) for Japan and Kleinert and Toubal (2007) for Germany. In studies concomitant to the present one, Barba Navaretti et al. (2010) for France and Italy, and Debeare et al. (2010) for Korea analyse the causal effects of becoming a multinational whilst distinguishing between high- and

\footnotetext{
${ }^{1}$ The main concern is in this case to evaluate whether exporters are better performers because of selfselection into export market or whereas this reflects learning-by-exporting (see amongst others Clerides et al., 1998; Girma et al., 2004).
} 
low-income investment locations. ${ }^{2}$ Becker and Mündler (2008), based on linked employer-employee data, use propensity score matching techniques to show that foreign expansion induces German MNEs to retain more domestic jobs than their domestic competitors. Noteworthily, these studies are all restricted to the manufacturing sector.

In the present paper, we approach the issue of relocation by focusing on the causal effects of decisions by firms to globalise their production, i.e. to become multinational, on the parent firm at home. For this purpose, we use rich firm-level data for France that cover the period 1987-1999. France is an interesting case given the intensity of globalisation debate: concerns over "délocalisations" (the French term referring to relocation abroad of production units) were according to the Eurobarometer the main reason for the no-vote in the referendum on the EU Constitution in 2005.

The contribution of this paper to the literature is twofold. First, we do not restrict our analysis to manufacturing, but separately analyse the effects of becoming a multinational for manufacturing and services firms. The relocation of services activities has become more important in recent years and it is sometimes feared that the employment consequences in the home country might be even more widespread than in the case of manufacturing. Second, we analyse the causal effect of becoming multinational whilst differentiating between horizontal, vertical or complex investment strategies on the basis of the location of investment (high or low income) and the industry affiliation (with comparative advantage or comparative disadvantage) of the investing firm.

Our main conclusion is that differentiating between investment strategies is crucial if one wants to grasp the effects of outward investment in the home country. In manufacturing, market-seeking investments have positive employment effects, whilst vertical investments mainly transform the investing firm's production function. Foreign direct investment (FDI) in the services sector is also associated with significant positive employment effects, which may reflect the possibility that FDI in this sector is

\footnotetext{
${ }^{2}$ A substantial number of papers however has looked at the related but different issue of the effects of foreign takeovers on local plants. See for example Arnold and Javorcik (2009) and Girma and Görg (2007).
} 
predominantly motivated by market access considerations. These results contradict popular fears about the potential negative employment impact of FDI abroad.

The remainder of this paper is structured as follows. Section 2 lays out the set-up. Section 3 discusses the matching methodology. Section 4 describes the data used for this study. Section 5 analyses the determinants of becoming a multinational in order to construct an appropriate counterfactual needed to evaluate the effects of investing abroad. Section 6 presents the results. Section 7 concludes.

\section{Set-Up}

Traditionally, the literature on FDI has identified two leading motives for establishing an affiliate abroad: the market-seeking (or 'horizontal') motive and the factor-seeking (or 'vertical') motive. Recently, interest has been directed to so-called complex FDI strategies, where foreign affiliates may be established because of a combination of horizontal and vertical motives, or where multinationals may consist of several foreign affiliates, some of which horizontal and others vertical (see e.g. Yeaple 2003).

Acknowledging these different motives is important in the context of the present paper because the impact of FDI on domestic firm outcomes is likely to depend upon the underlying strategy.

- The impact of FDI on domestic employment is likely to be more negative for vertical FDI than for horizontal FDI: whereas "pure" horizontal FDI is only intended for production sold on foreign markets, vertical FDI may lead to the relocation of all activities that can be produced more cheaply under the host country's factor prices. However, its impact on domestic employment is not necessarily negative. The direct negative impact of relocation on employment may be offset by positive indirect employment effects associated with relocation in the form of: i) production complementarities due to greater co-ordination and 
management needs; ii) scale effects that follow from the impact of relocation on average costs. ${ }^{3}$

- The impact of FDI on skill-intensity is expected to be either positive or insignificant. Vertical FDI is effectively a form of skill-biased technological change in which the production process is geographically fragmented. To the extent that low-skilled intensive activities are relocated abroad, this will increase the average skill-intensity for the investing firm at home. However, horizontal FDI may also have a positive impact on skill-intensity when relatively skillintensive headquarter services are retained at home.

- The impact of FDI on the productivity of domestic inputs is likely to be positive, but especially so for vertical FDI. Horizontal FDI may engender productivity improvements through firm-level economies of scale based on shared sunk costs (for instance, in R\&D), information sharing across affiliates, or learning-by-doing. A priori, more significant productivity gains are expected from vertical FDI: the perspective of a deeper division of labour that motivates such investments allows the parent firm to specialise in those production activities in which it is most efficient.

- Horizontal FDI is expected to reduce exports as it arises from the trade-off between concentrating production in one location and increasing market proximity through local production. Vertical FDI is expected to increase exports as intermediate inputs are shipped to foreign production sites for further processing.

While we do not have any direct information about investment motives, existing theories suggest that these motives should be closely related to two observable variables, namely industry-level skill-intensity and investment location. Indeed, horizontal models of multinational firms à la Markusen (1984) predict that multinational activity arises between similar countries due to the role of 'joint production'. Implicitly,

\footnotetext{
${ }^{3}$ Another reason why vertical FDI usually raises more important social concerns than horizontal FDI is that the jobs destroyed as a result of relocation tend to be very different from those created as a result of indirect effects.
} 
however, the rationale for such activity only exists insofar as the mother firms attracts enough demand in the host country and transportation costs are important, a situation more likely if the home country has a comparative advantage, which for a country like France should be the case in skill-intensive industries. In addition, the knowledgecapital model (see e.g. Markusen and Maskus 2001) shows that the benefits from fragmentation inherent to vertical investment derives from the cost savings associated with the exploitation of factor price differences across countries . For a high-income country like France, low-income countries are naturally the most attractive in the context of such strategies, whereby the low-skill intensive production stages are carried out by the foreign affiliate.

For our empirical analysis, we therefore assume that the underlying investment strategy can be characterised by a combination of industry affiliation and location choice: investments by firms from skill-intensive industries in high-income locations are assumed to reflect pure horizontal strategies; investments by firms from low skillintensive industries in low-income countries are considered to follow vertical strategies. All strategies that are not fully consistent with these two stylised cases are classified as complex. ${ }^{4}$ The importance of the distinction between investments in high- and lowincome locations has already been emphasised in several studies about the impact of foreign investment upon labour demand (e.g. Head and Ries 2002, or Harrison et al. 2007). Compounding this criterion with industry affiliation allows the investment motive to be captured more appropriately by taking account for a country's comparative advantage.

In order to allow for the possibility that the impact differs according to the location of the newly established affiliate, we extend the standard single treatment analysis to a multiple treatment setting (see Section 3 for more details on the methodology). ${ }^{5}$ It is assumed that each firm can only invest in one location at a time so that each firm only

\footnotetext{
${ }^{4}$ As we are only interested in firms that establish a first foreign affiliate, complex forms of foreign direct investment necessarily reflect establishments which are likely to be motivated by both horizontal and vertical motives. While theoretically the effects of complex forms, as defined here, on observable outcomes at home simply present a linear combination of the two pure investment strategies, failure to disentangle those different forms empirically does not allow one to grasp their implications appropriately. ${ }^{5}$ See Lechner (2001) and Blundell et al. (2005) for more details on multiple treatment effects.
} 
receives one single treatment or no treatment at all. ${ }^{6}$ When the expected outcomes of becoming a multinational further depend on a firm's individual characteristics, treatment effects are said to be 'heterogeneous'. While our methodology takes account of this, it may still be interesting to analyse how the average treatment effect changes over different segments of the population: this is done here by assessing separately the impact for firms in skill-intensive and non-skill-intensive industries.

Since the investment typology discussed so far has been essentially developed for manufacturing sectors, applying it to service activities is not straightforward. Unlike manufacturing goods, services trade does not entail transportation costs in the traditional sense. However, services do tend to be costly to trade, because they frequently require proximity between provider and user. Indeed, this "proximity burden", as Francois and Hoekman (2010) call it, implies that the vertical model of integration is irrelevant for a number of service activities as this involves increasing the distance between providers and users. For this reason, the market seeking motive is widely seen as the dominant motive for FDI in services (see Francois and Hoekman 2010, for a survey and Kolstad and Villanger 2008 for recent estimates). In service activities, the impact of FDI should thus closely correspond to that of horizontal FDI in manufacturing, although there may be an additional effect on skill-intensity due to the greater need for co-ordination activities in the context of FDI in services. ${ }^{7}$

Given the dominant role of the market-seeking motive for FDI in services, the initial level of skill-intensity in the home firm, closely related to a firm's comparative advantage, may be of less relevance in the context of services FDI. Moreover, the link between FDI and skill intensity is weaker than for manufacturing, since most French

\footnotetext{
${ }^{6}$ As discussed below, this is true with very few exceptions, which we classify as investors in a highincome location.

7 Nevertheless, the improvement of information and communication technologies has rendered the proximity requirement less systematic, as illustrated by the growing concerns surrounding services offshoring. Moreover, given the importance of producer services for manufacturing production, the increasing international fragmentation of production has tended to go hand-in-hand with FDI in services, since multinational firms often need their service providers to extend in parallel to them. However, the link between FDI in manufacturing and FDI services does not appear to have much bearing on the impact of FDI in services on the parent firm, except perhaps an additional need for co-ordination, a rather skillintensive activity.
} 
services FDI takes place in skilled-intensive sectors, with the exception of hotels and restaurant. We therefore did not retain the distinction between skill- and non-skillintensive sectors for the analysis of FDI in services. ${ }^{8}$ In contrast, distinguishing investments by location may still be useful, since FDI in high-income locations is likely to reflect market-seeking FDI, while FDI to low-income locations is likely to be linked to outsourcing by manufacturing firms. More generally, Bloningen and Wang (2005) emphasize the deep differences in determinants and consequences of FDI in developed and developing countries. In what follows, the analysis of services thus only retains the distinction between high- and low-income locations. ${ }^{9}$

\section{Methodology}

We borrow from the evaluation literature to evaluate the causal effect of initiating production in foreign location $j$ (treatment $j$ ) on a range of mutually exclusive outcomes relative to that of remaining national. The observed outcome of an individual firm $i, y_{i}$ can be written as:

$$
y_{i}=y_{i}^{0}+\sum_{j=1}^{J}\left(y_{i}^{j}-y_{i}^{0}\right) D_{i j}
$$

where superscript 0 refers to the case of non-treatment, and $j$ to treatment $j$. The number of different treatments considered is $J$, equal to two in our case (investment in a low- or in a high-income location). The dummy variable $D_{i j}$ equals one if firm $i$ follows treatment $j$. The crucial problem in the evaluation literature is the missing data problem, i.e. the fact that the outcome of individual $i$ had it not been treated, $y_{i}^{0}$, is unobserved. The main challenge therefore is to construct an appropriate counterfactual that can be used instead of $y_{i}^{0}$. Several methodologies have been proposed that attempt to do this.

\footnotetext{
${ }^{8}$ However, it would still be interesting to analyze how the impact of services FDI differs across services activities since the nature of FDI is likely to differ substantially across say business services, transportation services and hotels and restaurants. Unfortunately, the relatively small number of foreigndirect investments in services and their concentration in business and computing services does not allow us to make meaningful comparisons of the impact of services FDI across sectors. The sectoral breakdown of the estimation sample of matched firm pairs is shown in Appendix Table 1.

${ }^{9}$ As emphasized below, the sector classification concerns the activity of the investing firms, not of its affiliates. Our analysis thus concerns investment by service firms. However, it is not clear how important that difference is in practice. We implicitly assume that services firms invest in services sectors abroad.
} 
However, none strictly dominates the others. The ultimate choice of methodology therefore rests on the specific problem at hand. ${ }^{10}$

We adopt matching techniques in combination with a DID estimator to evaluate the causal effect of establishing a foreign affiliate on a set of domestic outcome variables of interest. Matching is an essentially non-parametric method which focuses on the mean difference in outcomes between the treated and the untreated over the common support, appropriately weighted by the distribution of participants. ${ }^{11}$ Matching involves reconstructing the missing data ex post for the treated outcomes had they not been treated when a randomised control group is not available. It does so by 'matching' firms from the group of untreated firms that are very similar in their pre-treatment observable characteristics to the treated. Once matched, the only observable difference between treated and untreated individuals is their treatment status. Using our matched control group, we analyse the average effect of the treatment on the treated (ATT):

$$
\hat{\alpha}_{A T T}^{j}=E\left(y_{i}^{j}-y_{i}^{0} \mid D_{i j}=1\right)=E\left(y_{i}^{j} \mid D_{i j}=1\right)-E\left(y_{i}^{0} \mid D_{i j}=1\right)
$$

The matching method relies on two assumptions: the conditional mean independence assumption (CIA) and the common support assumption (CS). First, CIA requires that conditional on observables the non-treated outcomes are independent of treatment status:

$$
E\left(y_{i}^{0} \mid X, D_{i j}=0\right)=E\left(y_{i}^{0} \mid X, D_{i j}=1\right) \text { for } X \in S
$$

The violation of this assumption results in selection bias the crux of the evaluation problem. Heckman et al. (1997) list three sources of selection bias, that would correspond to the following situations, in our case: i) the outcome variables are measured differently for treated and untreated, ii) differences arise in average outcomes across different markets, and iii) firms self-select into multinationals on the basis of unobservable characteristics. Consequently, the effectiveness of matching in reconstructing the unobserved counterfactual depends on three conditions: i) the data used to characterise the treated and the untreated come from a single source, ii) treated and untreated individuals reside in the same market, iii) the data contain a rich set of

\footnotetext{
${ }^{10}$ See Blundell and Costa Dias (2002) for a survey of the alternative approaches to evaluation problems.

${ }^{11}$ Consequently, in contrast to ordinary least squares, matching does not rely on assumptions regarding functional form (i.e. linearity) and homogenous treatment effects (that the treatment effect is identical across individuals).
} 
variables that affect participation and performance. In the present case data on firm characteristics all come from a single source. ${ }^{12}$ In order to satisfy the second requirement, matching is applied sector by sector. Finally, the present study uses administrative data for France which contains a wealth of information on almost the entire population of firms.

Second, the common support assumption requires that all treated firms have a counterpart in the untreated population and all firms have a positive probability of investing abroad:

$$
0<P\left(D_{i j}=1 \mid X\right)<1
$$

We therefore impose this condition in our matching procedure. In practice, there may exist a trade-off between both assumptions. While more detailed information allows one to construct a 'better' counterfactual which is important for justifying the CIA, at the same time this may make it more difficult to find appropriate controls thereby restricting the common support (i.e. the generality of the results).

In order to implement matching one has to overcome the curse of dimensionality which complicates finding an appropriate counterfactual when firms differ along several dimensions. Rosenbaum and Rubin $(1983,1985)$ propose to match on the propensity score and show that CIA remains valid once this is done appropriately. ${ }^{13}$ In our case, this score is defined as the propensity to establish an affiliate abroad as a function of observable characteristics:

$$
E\left(D_{i j} \mid y, X\right)=P\left(D_{i j}=1 \mid X\right)
$$

In what follows, we will use the logit and the multinomial logit models to estimate the propensity score for the single and multiple treatment case respectively. Firms are matched using nearest neighbour (one-to-one) matching with replacement. Firms are matched separately for each year, each two-digit industry, for exporters and non-

\footnotetext{
${ }^{12}$ More specifically, the survey conducted by Direction des Relations Economiques Extérieures on French affiliates abroad is used to sort out the treated from the untreated, while the $E A E$ is used to analyse why firms decide to establish a foreign affiliate abroad and how this affects their performance. See below for details on data sources.

${ }^{13}$ More recently, Hahn (1998) has shown that using the propensity score may also improve the efficiency of ATT by reducing the number of dimensions.
} 
exporters. Throughout a condition is imposed that firms cannot be matched to firms belonging to the same business group.

We further improve the performance of propensity score matching by combining it with the DID estimator following Heckman et al. (1997) and Blundell et al. (2004). The CIA is a strong assumption once it is realised that firms base their investment decisions on future expected profits, which are unobserved by the econometrician. The DID estimator allows one to control for selection on time-invariant unobservable characteristics by focusing on the difference in the trend before and after treatment instead of that of the difference in levels. The CIA now requires that conditional on observables treatment status is independent of unobserved temporary individual-specific effects: ${ }^{14}$

$$
E\left(\Delta y_{i}^{0} \mid X, D_{i j}=0\right)=E\left(\Delta y_{i}^{0} \mid X, D_{i j}=1\right) \text { for } X \in S
$$

The DID estimator assumes that unobserved macro-economic developments affect the treatment and the control in the same way ('common trends assumption'). However, there may be unobserved differences that cause both groups to react differently in response to any observed shocks. We attempt to control for this by including observable characteristics that explain the propensity to invest abroad both in levels and firstdifferences.

\section{Data sources and descriptive statistics}

Data on individual firms are obtained from the Enquête Annuelle des Entreprises (EAE) which covers all industries and is available for the years 1984-2002. The survey comprises all firms with more than 20 employees in manufacturing; in services, it includes all firms with more than 30 employees (more than 20 before 1997), as well as a sample of firms under this threshold. ${ }^{15}$ Participation of firms to this survey is compulsory by law.

\footnotetext{
${ }^{14}$ In practical terms, implementing the DID estimator involves estimating a fixed effects model on the difference in the means between treated and untreated firms.

${ }^{15}$ The sampling method used in services since 1997 is based upon a threshold. This threshold is generally set at 30 employees or a turnover of at least 5 million euros. All firms beyond the threshold are systematically surveyed each year, while only a sample of other firms below the threshold are surveyed each year.
} 
We combine the EAE using the firm identifiers with the survey conducted by Direction des Relations Economiques Extérieures (DREE, French Ministry of Economics and Finance) on French affiliates abroad. We only use information on the year in which a firm establishes its first production establishment abroad, while disregarding distribution affiliates. Firms that have according to DREE at least one foreign affiliate are classified as multinational firms. Firms that do not have any foreign affiliate are considered purely national firms. The main focus here is on firms that switch from being national to multinational by establishing an affiliate abroad.

A third data set with information on business groups, LIFI (Liaisons Financières), is used to ensure that we do not match firms that are part of the same enterprise group. This is an important issue as it may be quite likely that we link firms within the same business groups due to the similarity of their observable characteristics. This, however, would give us a misleading picture of the causal effect of becoming a multinational as firms within the same business groups have strong financial linkages. As a result, any effect due to investing abroad by one firm in a business group may be spread through the entire business group, thus mitigating the difference between the treatment firm and its control.

The data only identify the activity of the investing firm, not of the affiliate. The categorisation of FDI by sector is thus based on the activity of the mother firm. This means in particular that we are only able to distinguish FDI by service firms, which may differ from investment in service activities both because services firms may invest in industrial activities (in particular when some products represent key inputs for the service firm), and conversely because manufacturing firms may invest in service activities (note however that we only consider production affiliates and disregard distribution affiliates).

In order to follow individual firms through time we organise the data around cohorts. Cohorts are defined as six-year windows centred around year $t^{*}$ in which domestic firms may establish a foreign presence. We impose the condition that within a six-year window the panel is balanced. ${ }^{16}$ After having defined the cohorts we stack them

\footnotetext{
${ }^{16}$ Strictly speaking, a sufficient condition would have been to require the panel to be balanced up to tstar, the year in which firms switch. However, having a completely balanced panel facilitates the
} 
together in order to create a 'panel of cohorts' running from 1987-1999 for manufacturing. Bender and Von Wachter (2006) observe that this effectively gives a system of seemingly unrelated regressions with cross-equation restrictions. They suggest that standard errors should be clustered within individuals to take account of the resulting correlation in the error structure. ${ }^{17}$

Not only do we need to construct an unobserved counterfactual but we also have to decide what the counterfactual is supposed to represent, an issue that not usually arises in the traditional evaluation literature. In contrast to most policy evaluation programmes that are administered at a certain point in time the choice to invest abroad can be taken at any point in time and may even be repeated. It is therefore not straightforward whether we should compare firms that invest abroad in year $t$ with firms that never invest abroad, or with firms that never invest abroad up to year $t$. Sianesi (2004) argues in the context of active labour market programmes in Sweden that the latter gives the relevant parameter "for it mirrors the relevant decision open to the job-seeker and the program administrator: to join a program at a given time or to wait at a bit longer, in the hope of finding a job and in the knowledge that one can always join later" (p. 133). Barba Navaretti et al. (2010) focus on the same parameter in their study of FDI. The question addressed is then that of becoming a multinational now rather than later instead of that of becoming a multinational now and remaining national forever after. This thus addresses the question of becoming a multinational now rather than later instead of the question of becoming a multinational now and remaining national forever after. We follow this approach in the present paper.

When distinguishing investment by location, we will consider high income OECD countries ('high income') and the rest of the world ('low income'). It is uncommon for a first-time investor to invest simultaneously in both a low- and a high-income country. ${ }^{18}$ However, when this is the case, we classify the investment in the high-income category only, so that the two categories we are considering are by definition mutually exclusive. We identify skill-intensive industries as those with above-average skill intensity. As already mentioned, we only apply this distinction to manufacturing.

interpretation of the results as it removes any effects which are due to changes in the composition of firms after t-star. Barba Navaretti et al. (2010) also use a balanced panel but do not define cohorts.

${ }^{17}$ A similar methodology is used in Jacobson et al. (1993).

${ }^{18}$ Only 12 such examples are found in the matched estimation sample for manufacturing, 9 for services. 
Figure 1 reports the total number of "switchers", i.e. the total number of national firms becoming multinationals by initiating production in either a high-income or a lowincome location, in our data for each year during the period 1987-1999. First-time foreign investments are about equally important in manufacturing and services. In both sectors, they are headed predominantly towards high-income countries and follow an increasing trend. Our data set includes a total of 404 switchers in manufacturing and 349 in services. Due to the requirements that all variables are non-missing for the whole time-window $[t-2 ; t+3]$ the actual estimation sample for the propensity score consists of 309 switchers in manufacturing and 185 in services. ${ }^{19}$

Figure 1: Number of new French multinationals considered by year, sector and investment location

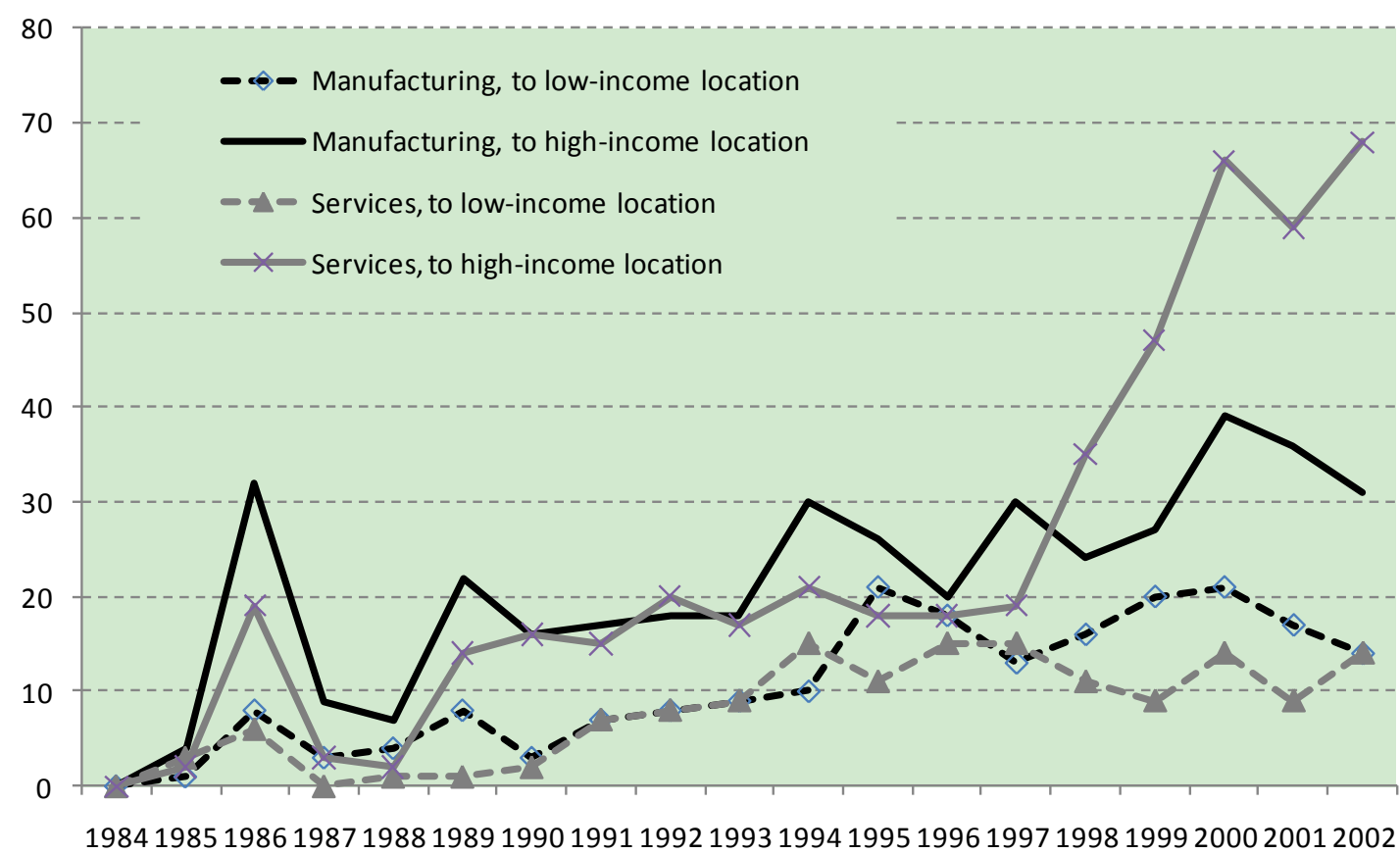

Note: The figure plots, for each year, the number of firms investing abroad for the first time, respectively in a high- and in a low-income location. Firms are classified in manufacturing or services according to the activity of the parent firm.

We next assess how the difference in export and FDI status is correlated with different firm characteristics by estimating regressions over all firms (with more than 20 employees in manufacturing, more than 30 in services) on a set of export and investment dummies along with additional controls. The first set of regressions only includes a set of time dummies (Table 1, Panel A); the second set in addition controls

\footnotetext{
${ }^{19}$ When imposing the common support, not all treated firms have a control on the common support. Accordingly, 286 matched firm pairs are studied below in manufacturing and 151 in services.
} 
for the region and sector of the firm (Panel B); and finally, the third set of regressions also includes log employment (Panel C).

Table 1 shows that exporters are larger and more productive than non-exporters, consistent with the theoretical literature following Mélitz (2003). They are also found to be more skilled and to own more intangible assets. These differences are large in most cases and robust to controlling for sector, region and firm employment. This is also in line with previous empirical evidence as presented for instance by Bernard's et al. (2007) for manufacturing firms in the United States. We show that this pattern also holds for services where exporters are far less numerous.

Table 1: Exporters, new investors abroad and multinationals, compared to other firms (1987-1999)

\begin{tabular}{rrrr}
\multicolumn{4}{c}{ Manufacturing } \\
\hline Exporter & New & New & \\
w/o & investor, to & investor, to & Multi- \\
foreign & low-income & high-income & national \\
affiliate & location & loc. & firms
\end{tabular}

\begin{tabular}{rrrr} 
Services & \\
\hline New & $\begin{array}{r}\text { New } \\
\text { Exporter } \\
\text { investor, } \\
\text { investor, } \\
\text { to low- } \\
\text { to high- }\end{array}$ Multi- \\
foreign & income & income & national \\
affiliate & location & loc. & firms
\end{tabular}

A. Additional controls: time dummies

$\begin{array}{lrrrrrrrr}\text { Log employment } & 0.44 & 1.80 & 2.05 & 2.59 & 0.14 & 1.14 & 1.16 & 1.45 \\ \text { Log value added } & 0.58 & 2.10 & 2.54 & 3.07 & 0.75 & 2.48 & 2.84 & 3.22 \\ \text { TFP } & 0.27 & 0.66 & 0.66 & 0.76 & 0.22 & 0.26 & 0.43 & 0.48 \\ \text { Average skill } & 0.10 & 0.17 & 0.24 & 0.29 & 0.35 & 0.47 & 0.53 & 0.60 \\ \text { Exports/turnover } & 0.18 & 0.31 & 0.32 & 0.35 & 0.16 & 0.12 & 0.09 & 0.12 \\ \text { Profit / turnover } & 0.01 & 0.02 & 0.04 & 0.03 & (0.00) & (0.00) & (0.02) & (0.02) \\ \text { Intangible assets / VA } & 1.69 & 5.29 & 6.59 & 6.40 & 0.75 & 4.20 & 4.15 & 4.33 \\ \text { Corporate taxes } & 0.55 & (1.23) & 2.08 & 1.28 & 1.16 & 3.27 & 4.65 & 3.91 \\ \text { Nb. plants } & 0.05 & 0.46 & 0.69 & 0.93 & \text { n.a. } & \text { n.a. } & \text { n.a. } & \text { n.a. }\end{array}$

B. Additional controls: time, region and sector dummies

$\begin{array}{lrrrrrrrr}\text { Log employment } & 0.38 & 1.68 & 1.90 & 2.40 & 0.10 & 1.00 & 1.09 & 1.36 \\ \text { Log value added } & 0.48 & 1.94 & 2.27 & 2.73 & 0.69 & 2.25 & 2.62 & 2.99 \\ \text { TFP } & 0.27 & 0.65 & 0.62 & 0.72 & 0.15 & 0.23 & 0.32 & 0.41 \\ \text { Average skill } & 0.07 & 0.13 & 0.14 & 0.17 & 0.26 & 0.40 & 0.40 & 0.49 \\ \text { Exports/turnover } & 0.17 & 0.28 & 0.29 & 0.31 & 0.17 & 0.13 & 0.10 & 0.11 \\ \text { Profit / turnover } & 0.01 & 0.02 & 0.04 & 0.02 & 0.01 & (0.00) & (0.02) & 0.02 \\ \text { Intangible assets / VA } & 1.53 & 4.92 & 6.13 & 5.83 & 0.76 & 4.03 & 4.15 & 4.20 \\ \text { Corporate taxes } & 0.51 & (1.19) & 2.01 & 1.19 & 0.95 & (2.47) & 4.44 & 3.22 \\ \text { Nb. plants } & 0.04 & 0.43 & 0.62 & 0.83 & \text { n.a. } & \text { n.a. } & \text { n.a. } & \text { n.a. }\end{array}$

C. Additional controls: time, region and sector dummies + Log employment

$\begin{array}{lllllllll}\text { Log value added } & 0.09 & 0.19 & 0.27 & 0.21 & 0.33 & 0.46 & 0.53 & 0.70 \\ \text { TFP } & 0.22 & 0.44 & 0.38 & 0.42 & 0.15 & 0.24 & 0.32 & 0.42\end{array}$




$\begin{array}{lrrrrrrrr}\text { Average skill } & 0.06 & 0.09 & 0.11 & 0.12 & 0.29 & 0.49 & 0.48 & 0.60 \\ \text { Exports/turnover } & 0.15 & 0.22 & 0.22 & 0.23 & 0.15 & 0.13 & 0.10 & 0.12 \\ \text { Profit / turnover } & 0.00 & (0.01) & 0.04 & 0.02 & 0.01 & (-0.02) & (0.00) & (-0.01) \\ \text { Intangible assets / VA } & 0.60 & 0.53 & 1.31 & (-0.22) & 0.60 & 1.76 & (1.23) & 1.31 \\ \text { Corporate taxes } & 0.56 & 1.38 & 2.24 & 1.53 & 0.41 & (0.47) & (2.04) & 0.91 \\ \text { Nb. plants } & -0.05 & (0.06) & 0.18 & 0.29 & \text { n.a. } & \text { n.a. } & \text { n.a. } & \text { n.a. }\end{array}$

Nb. observations

203,639

140

$264 \quad 4,526 \quad 45,678$

104

245

Note: The table reports the estimated coefficients for the dummies on export and investment status in a regression that also includes the additional controls described in panel headings A, B and C. Each row reflects the results from one regression for manufacturing and one for services. Firms are considered new investors the year when they invest abroad for the first time. Multinationals are defined as firms which invested abroad at least three years earlier. All results are significant at the $1 \%$ level, except those reported between parentheses. All enterprises with more than 20 employees are covered in manufacturing (277,350 observations in total or 21,335 per year on average), all enterprises with more than 30 employees are covered in services $(312,822$ observations in total or 24,063 per year on average).

Table 1 also confirms that foreign investors differ strikingly from mere exporters, consistent with Helpman et al. (2004). This is true in all the above-cited dimensions. In addition, new investors display intermediate characteristics between multinationals ${ }^{20}$ and simple exporters in almost all cases (in particular employment, value added and productivity), with firms investing in high-income locations more closely resembling multinationals than those investing in low-income countries. For instance, controlling for time, sector and region, exporters without foreign affiliate employ $47 \%$ more workers than non-exporters in manufacturing (exp(0.38)-1), while the differential is $436 \%$ and $569 \%$ for first-time investors respectively in low- and high-income locations, and $1008 \%$ for multinationals (still with respect to domestic non-exporters). This confirms the need to control for the ex ante specificities of new foreign investors, as well as the interest of distinguishing investors to low- and high-income locations.

\section{Constructing the Counterfactual}

The propensity scores are estimated based on a multinomial logit model of the propensity of a domestic firm to establish an affiliate abroad. Before going on to the estimations, one has to decide on the appropriate number of lags. Most studies looking at either the decision to export or invest abroad use explanatory variables in the last year before investment takes place (or before one starts exporting). This approach may be unsatisfactory when the decision to invest is taken one or two years before the

\footnotetext{
${ }^{20}$ The definition of multinationals is restricted here to firms having invested abroad at least three years before.
} 
investment takes place and when the decision to invest is taken in conjunction with other decisions that affect the observable characteristics of the firm. In this case, part of the causal effect due to the decision to invest abroad may actually occur before the year of the investment. ${ }^{21}$ We prefer the specification with two lags as it allows for some anticipatory effects, but does not restrict our ability by too much to follow matched firms after investing abroad.

Table 2 reports the results obtained from the multinomial logit regressions for manufacturing and services respectively. The propensity of domestic firms to become multinational is considered to be a function of the log of employment, log exports over value added, total factor productivity (TFP), profits over value added, the log wage bill per worker, log intangible assets over value added, log corporate taxes over turnover, the log number of production plants (in manufacturing only), the log change in value added, the change in profits over value added. The regressions also include a full set of region, sector and time dummies. Multinational firms are excluded from the sample.

Table 2:

Propensity to Switch Manufacturing

\begin{tabular}{|c|c|c|c|c|c|c|c|c|c|c|c|c|}
\hline \multirow{4}{*}{$\operatorname{Ln} \mathrm{VA}_{t^{*}-2}$} & \multicolumn{6}{|c|}{ Manufacturing } & \multicolumn{6}{|c|}{ Services } \\
\hline & \multirow{2}{*}{\multicolumn{2}{|c|}{ All }} & \multicolumn{4}{|c|}{ Location's income } & & & \multicolumn{4}{|c|}{ Location's income } \\
\hline & & & High & & Low & & All & & High & & Low & \\
\hline & $\begin{array}{r}3.04 \\
(2.66)\end{array}$ & $* * *$ & $\begin{array}{r}2.56 \\
(1.60)\end{array}$ & & $\begin{array}{r}3.51 \\
(2.66)\end{array}$ & $* * *$ & $\begin{array}{r}1.06 \\
(1.51)\end{array}$ & & $\begin{array}{r}2.77 \\
(2.49)\end{array}$ & $* *$ & $\begin{array}{r}-0.23 \\
(-0.23)\end{array}$ & \\
\hline Squared $\ln \mathrm{VA}_{\mathrm{t}^{*-2}}$ & $\begin{array}{r}-0.13 \\
(-2.68)\end{array}$ & $* * *$ & $\begin{array}{r}-0.13 \\
(-2.06)\end{array}$ & $* *$ & $\begin{array}{r}-0.11 \\
(-1.94)\end{array}$ & * & $\begin{array}{r}-0.05 \\
(-1.77)\end{array}$ & $*$ & $\begin{array}{r}-0.11 \\
(-2.44)\end{array}$ & $* *$ & $\begin{array}{r}-0.03 \\
(-0.66)\end{array}$ & \\
\hline Ln Employment $t_{t^{*}-2}$ & $\begin{array}{r}0.52 \\
(1.08)\end{array}$ & & $\begin{array}{r}1.12 \\
(2.05)\end{array}$ & $* *$ & $\begin{array}{r}-0.18 \\
(-0.32)\end{array}$ & & $\begin{array}{r}0.82 \\
(2.48)\end{array}$ & $* *$ & $\begin{array}{r}0.52 \\
(1.59)\end{array}$ & & $\begin{array}{r}1.48 \\
(1.89)\end{array}$ & * \\
\hline Ln Exports $t_{t^{*}-2}$ & $\begin{array}{r}0.10 \\
(4.12)\end{array}$ & $* * *$ & $\begin{array}{r}0.12 \\
(3.51)\end{array}$ & $* * *$ & $\begin{array}{r}0.07 \\
(2.09)\end{array}$ & $* *$ & $\begin{array}{r}0.02 \\
(2.06)\end{array}$ & $* *$ & $\begin{array}{r}0.01 \\
(0.97)\end{array}$ & & $\begin{array}{r}0.04 \\
(2.61)\end{array}$ & $* * *$ \\
\hline $\mathrm{TFP}_{\mathrm{t}^{*}-2}$ & $\begin{array}{r}0.40 \\
(2.23)\end{array}$ & $* *$ & $\begin{array}{r}0.43 \\
(2.08)\end{array}$ & $* *$ & $\begin{array}{r}0.45 \\
(1.55)\end{array}$ & & $\begin{array}{r}0.43 \\
(1.26)\end{array}$ & & $\begin{array}{r}0.20 \\
(0.58)\end{array}$ & & $\begin{array}{r}1.07 \\
(1.41)\end{array}$ & \\
\hline Ln Average Wage $t_{t^{*}-2}$ & $\begin{array}{r}-0.46 \\
(-0.88)\end{array}$ & & $\begin{array}{r}0.34 \\
(0.55)\end{array}$ & & $\begin{array}{r}-1.59 \\
(-2.21)\end{array}$ & $* *$ & $\begin{array}{r}1.03 \\
(3.55)\end{array}$ & $* * *$ & $\begin{array}{r}0.76 \\
(2.17)\end{array}$ & $* *$ & $\begin{array}{r}1.41 \\
(2.54)\end{array}$ & $* *$ \\
\hline Profits $_{t *-2}$ & $\begin{array}{r}1.16 \\
(0.72)\end{array}$ & & $\begin{array}{r}4.19 \\
(2.32)\end{array}$ & $* *$ & $\begin{array}{r}-3.36 \\
(-1.82)\end{array}$ & $*$ & $\begin{array}{r}-0.41 \\
(-0.63)\end{array}$ & & $\begin{array}{r}-0.70 \\
(-0.97)\end{array}$ & & $\begin{array}{r}0.11 \\
(0.08)\end{array}$ & \\
\hline Ln Intangible Assets ${ }_{t^{*}-2}$ & $\begin{array}{r}0.05 \\
(3.15)\end{array}$ & $* * *$ & $\begin{array}{r}0.07 \\
(3.37)\end{array}$ & $* * *$ & $\begin{array}{r}0.02 \\
(0.69)\end{array}$ & & $\begin{array}{r}0.03 \\
(1.15)\end{array}$ & & $\begin{array}{r}0.01 \\
(0.29)\end{array}$ & & $\begin{array}{r}0.06 \\
(1.58)\end{array}$ & \\
\hline${ }_{\text {Ln Corporate Taxes }}{ }_{t^{*}-2}$ & $\begin{array}{r}0.03 \\
(2.20)\end{array}$ & $* *$ & $\begin{array}{r}0.02 \\
(1.32)\end{array}$ & & $\begin{array}{r}0.05 \\
(1.93)\end{array}$ & $*$ & $\begin{array}{r}0.03 \\
(2.15)\end{array}$ & $* *$ & $\begin{array}{r}0.03 \\
(2.19)\end{array}$ & $* *$ & $\begin{array}{r}0.01 \\
(0.60)\end{array}$ & \\
\hline$\Delta \ln$ Value added ${ }_{t^{*}-2}$ & $\begin{array}{r}0.40 \\
(1.07)\end{array}$ & & $\begin{array}{r}0.53 \\
(1.21)\end{array}$ & & $\begin{array}{r}0.13 \\
(0.23)\end{array}$ & & $\begin{array}{r}1.53 \\
(3.93)\end{array}$ & $* * *$ & $\begin{array}{r}1.19 \\
(2.55)\end{array}$ & $* *$ & $\begin{array}{r}1.61 \\
(2.71)\end{array}$ & $* * *$ \\
\hline
\end{tabular}

\footnotetext{
${ }^{21}$ In a manner similar to the Ashenfelter dip in the labour economics literature.
} 


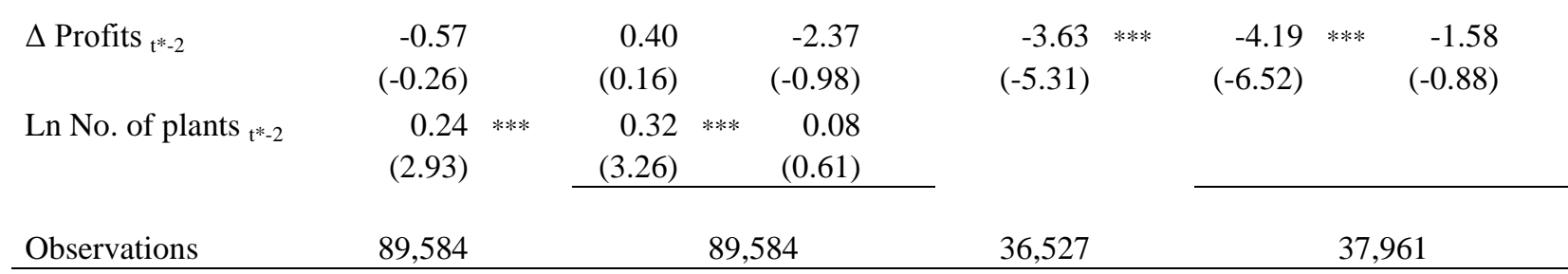

Note: $*, * *, * * *$ statistically significant at $10 \%, 5 \%$ and $1 \%$. Robust standard errors in parentheses. All regressions include full set of industry, region and time dummies. Columns "All" report the results of a simple logit model, while columns by location's income ("High" and "Low") jointly report the results of a multinomial logit model.

The propensity of firms to establish a foreign presence abroad is consistently found to depend upon the parent's scale, whether measured through either value added or employment. Although the corresponding coefficients are not always significant, the propensity to invest abroad also depends positively on the level of exports, TFP, intangible assets, and corporate taxes. These results are in line with the descriptive statistics above and the theoretical predictions in Helpman et al. (2004).

The average wage is of particular relevance in the present paper as it is used to classify industries into low and high-skill intensive industries. ${ }^{22}$ In manufacturing, the results indicate that firms paying below-average wages in their sector -and therefore presumably employ a relatively less skilled workforce-are more prone to investing in low-income countries, consistent with our priors on vertical FDI. In services, by contrast, the average wage is estimated to have a positive and significant impact on the propensity to invest abroad whatever the location consistent with the market-seeking perspective of FDI, presumably reflecting the importance of market-access considerations in driving service investments abroad.

The propensity scores are used to construct the unobserved counterfactual, i.e. to match switching firms to non-switching domestic firms which are similar in terms of their observable characteristics. While treated firms differ significantly and substantially from other firms in most respects, the balancing tests reported in Appendix Table 2 show that the matching procedure satisfactorily removes these differences.

\footnotetext{
${ }^{22}$ Since differences in average wage are more likely to result from differences in the composition of the workforce than pay differences across firms for similar workers we interpret this variable as a measure of skill-intensity.
} 


\section{Results}

Using the matched sample we now analyse the causal effect of initiating production abroad. Rather than analysing the differences in the means between the treated and the controls at arbitrary points in time, we use our data set of stacked cohorts to track average differences over time. We first consider the impact of different FDI strategies on parent exports, then discuss its implications for parent employment and close with an analysis of FDI on technology.

\subsection{International investment strategies and firm-level exports}

As emphasised above, differences in investment motives can be a useful guide to interpret the employment effects of investment projects. Absent the possibility to ask firms about their motives, we argued in Section 2 that the combination of industry affiliation (high-skill intensive versus low-skill intensive) and income location choice (high income versus low income) allows obtaining a simple characterisation of different FDI strategies. Given the widely different implications of horizontal and vertical FDI for exports, the estimated causal effects of FDI on exports provide a rough test of the appropriateness of this characterisation.

\section{Figure 2: Impact of FDI on Log Exports}
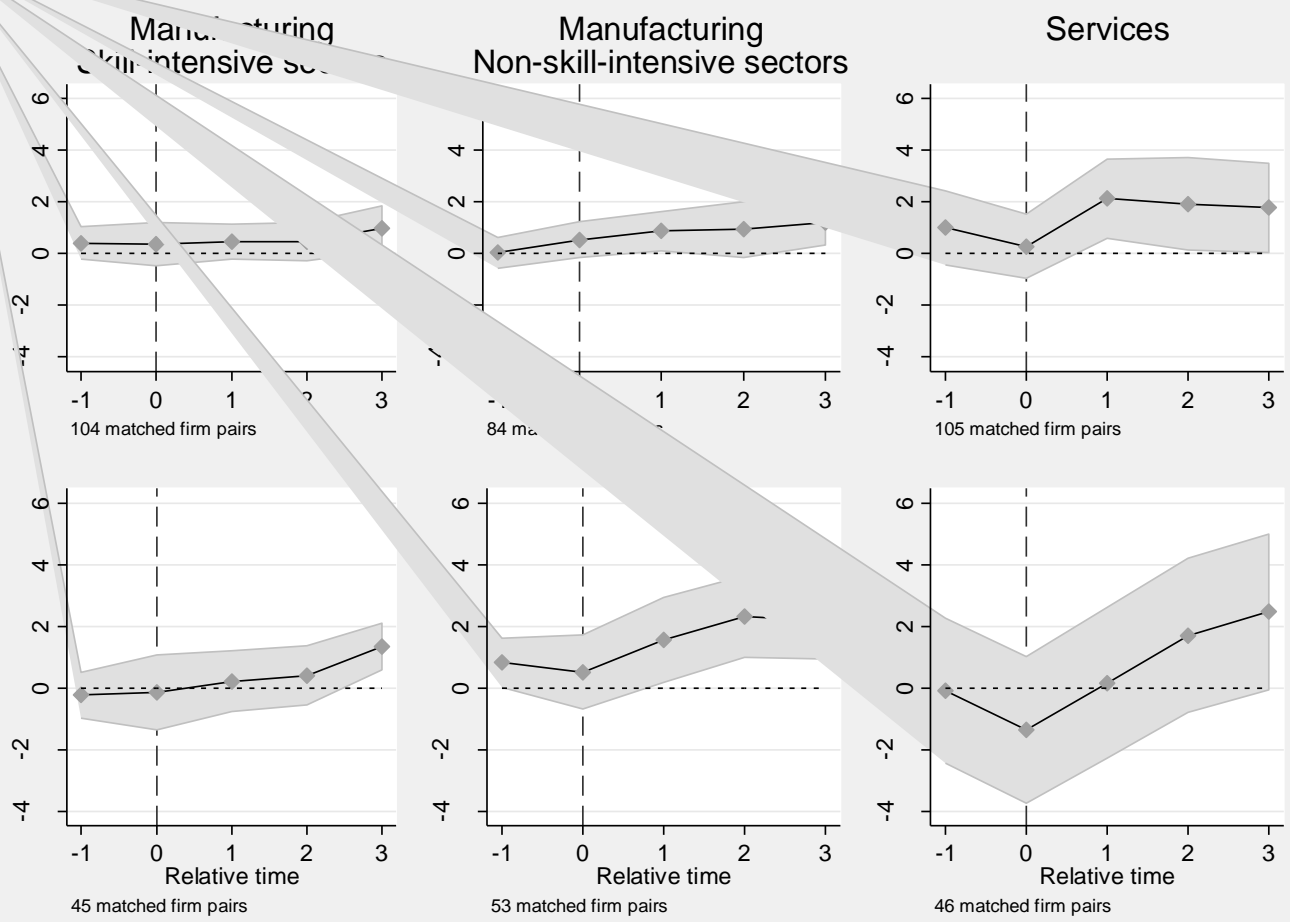
Notes: Relative time is zero for the year when foreign investment takes place. The dependent variable is the change from $\mathrm{t}-2$ in the difference in the log of exports between first-time investors and the matched control group. The solid line represents the average impact; the shaded area corresponds to the associated $95 \%$ confidence interval, based on bootstrapped standard errors, clustered on individual firms (100 replications).

The estimates reported in Figure 2 lend support to the typology proposed above: FDI in low-income countries by manufacturing firms in comparative-disadvantage sectors are associated with strongly increased exports (ceteris paribus, their level is multiplied by almost nine with respect to the control group), consistent with the assumption that such situations reflect vertical, or factor-seeking, FDI. In contrast, investments in highincome locations by firms in skill-intensive sectors are not associated with a statistically significant effect on exports, consistent with the prior that they are horizontal, marketseeking investments. The intermediate results found for the remaining two cases also support the idea that they reflect complex motives, mixing factor- and market-seeking strategies.

Our typology does not apply to service firms. The estimated export effects of initiating production abroad is positive for service firms, whatever the location, although somewhat imprecise. These results could reflect the existence of a division of labour between the parent firm and its affiliate, but also the existence of production complementarities, which are likely in particular for business services.

\subsection{International investment strategies and firm-level employment}

The results confirm the prior that horizontal FDIs are the most beneficial in terms of employment in the parent firm (Figure 3). For a firm in a skill-intensive industry that invests in a high-income location, employment is $16 \%$ higher three years after investment relative to its counterfactual outcome that would have emerged had it not invested abroad and it is increasing over time. In contrast, vertical FDI associated with firms in comparative disadvantage industries that invest in low-income locations, does not have a statistically significant effect on employment which, if anything, appears to decrease over time. Complex FDI exhibits intermediate results, positive but only significant in the case of firms in skill-intensive industries investing in low-income countries. 
Figure 3: Impact of FDI on Log Employment
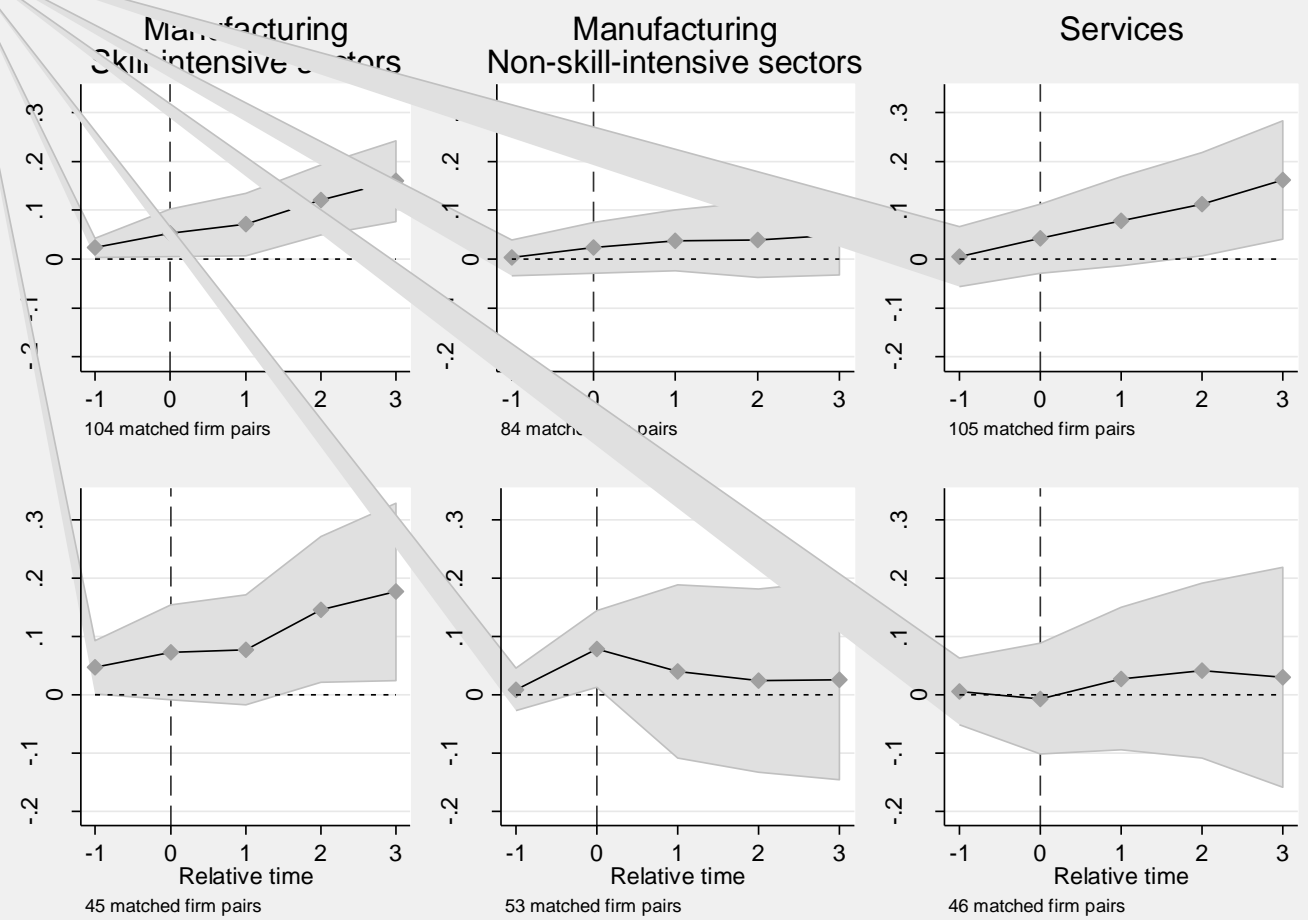

Notes: Relative time is zero for the year when foreign investment takes place. The dependent variable is the change from $\mathrm{t}-2$ in the difference in the log of exports between first-time investors and the matched control group. The solid line represents the average impact; the shaded area corresponds to the associated $95 \%$ confidence interval, based on bootstrapped standard errors, clustered on individual firms (100 replications).

For services FDI, a large and significant positive impact is found in the context of investments in high-income locations $(+17 \%$ three years after investment, significant at the $1 \%$ level), comparable to the effect found for horizontal investments in manufacturing. Investments in low-income locations are found to have a small positive, but insignificant impact on employment.

Remarkably, among the various configurations studied, no sign could be found of any negative effect on the parent firm's employment. As a robustness check, the employment impact was estimated by adding the log wage as an additional control. These semi-parametric estimates were very close to the one presented above (see Appendix Table 3). 


\subsection{International investment strategies, the input mix and efficiency}

Figure 4 represents the trajectories of the capital-labour ratio relative to our reconstructed counterfactual by location and type of industry. For horizontal FDI the estimated impact is negative, but not statistically significant. In principle, this could reflect the role of production complementarities associated with such investments in the form of greater co-ordination and management needs. Such production complementarities may be particularly important for services investment abroad. By contrast, vertical FDI is found to increase the capital-labour ratio. While these estimates are only significant at the $10 \%$ level, they are consistent with vertical FDI allowing further division of labour across affiliates, with the parent firm retaining the most capital-intensive parts of the production process. A qualitatively similar pattern is obtained when replacing the average wage, a rough measure of skill-intensity, instead of the capital-labour ratio (with no change for horizontal FDI and a slight increase for vertical FDI). These results are reported in Figure 1 of the Appendix.

Figure 4: The Impact of FDI on Capital-Labour Ratio
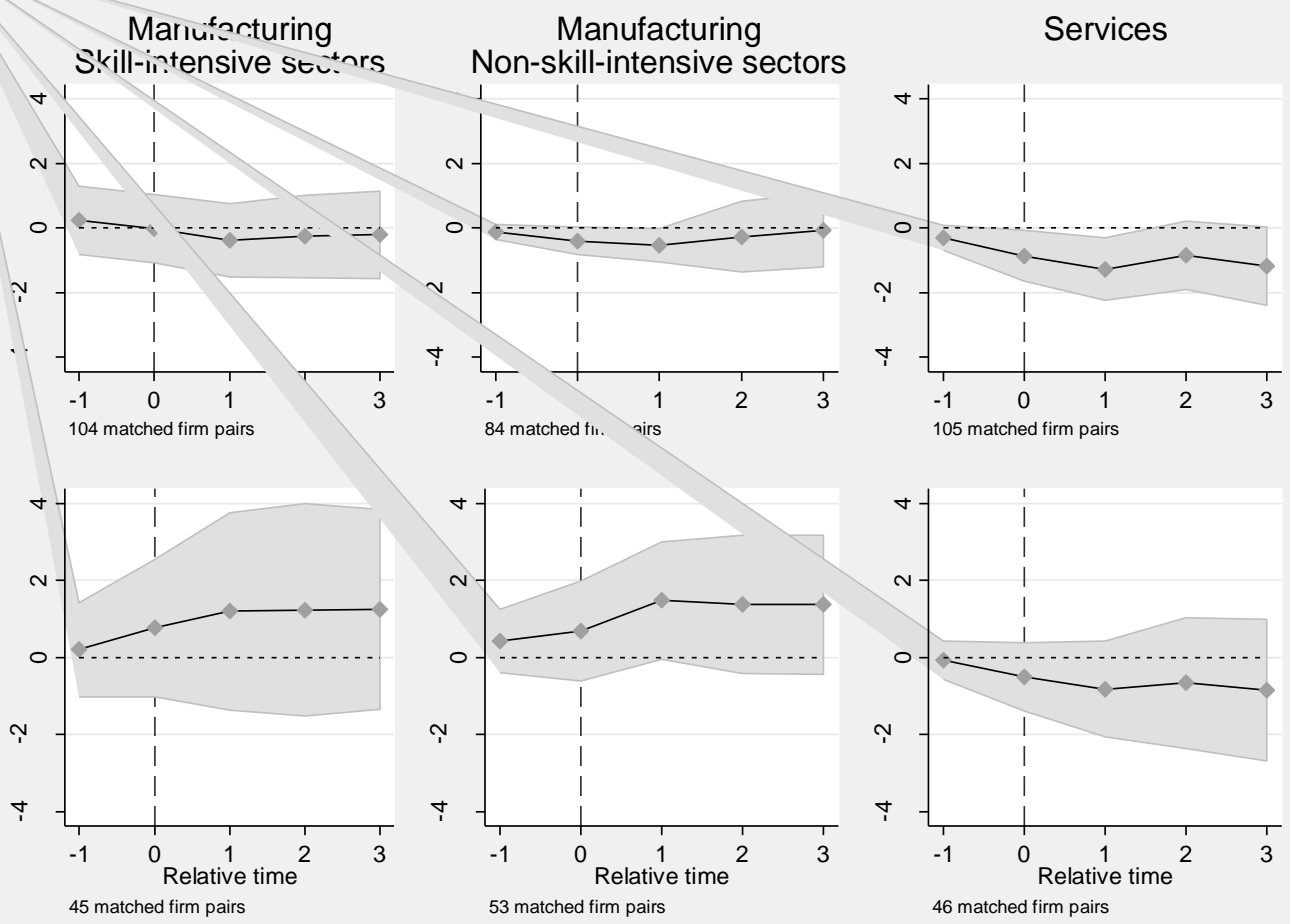

Notes: As in Figure 2. The dependent variable is the capital-labour ratio, computed as fixed assets per employee. 
Figure 5 reports the estimated effects of FDI on TFP by international investment strategy. The efficiency gains associated with vertical FDI could be potentially large, but lack precision. Nevertheless, they are fully consistent with the idea that the division of labour across affiliates is a source of efficiency gains. There is no indication that similar efficiency gains may also arise for horizontal FDI. For complex FDI, statistically significant efficiency gains are found for firms in non-skill-intensive sectors investing in high-income locations, perhaps as a result of outsourcing those fragments of the production process in which they were least efficient. No such effect is found for firms in skill-intensive sectors investing in low-income locations or for services firms.

As a robustness check, semi-parametric estimates are carried out for TFP, adding firm turnover as an additional control (see Appendix Table 4). Although qualitatively comparable to the results presented in Figure 5, the estimated TFP impacts are systematically lower due to the positive impact of FDI on turnover. This suggest that part of the efficiency gains mentioned could reflect economies of scale that arise from greater specialisation.

Figure 5: The Impact of FDI on TFP
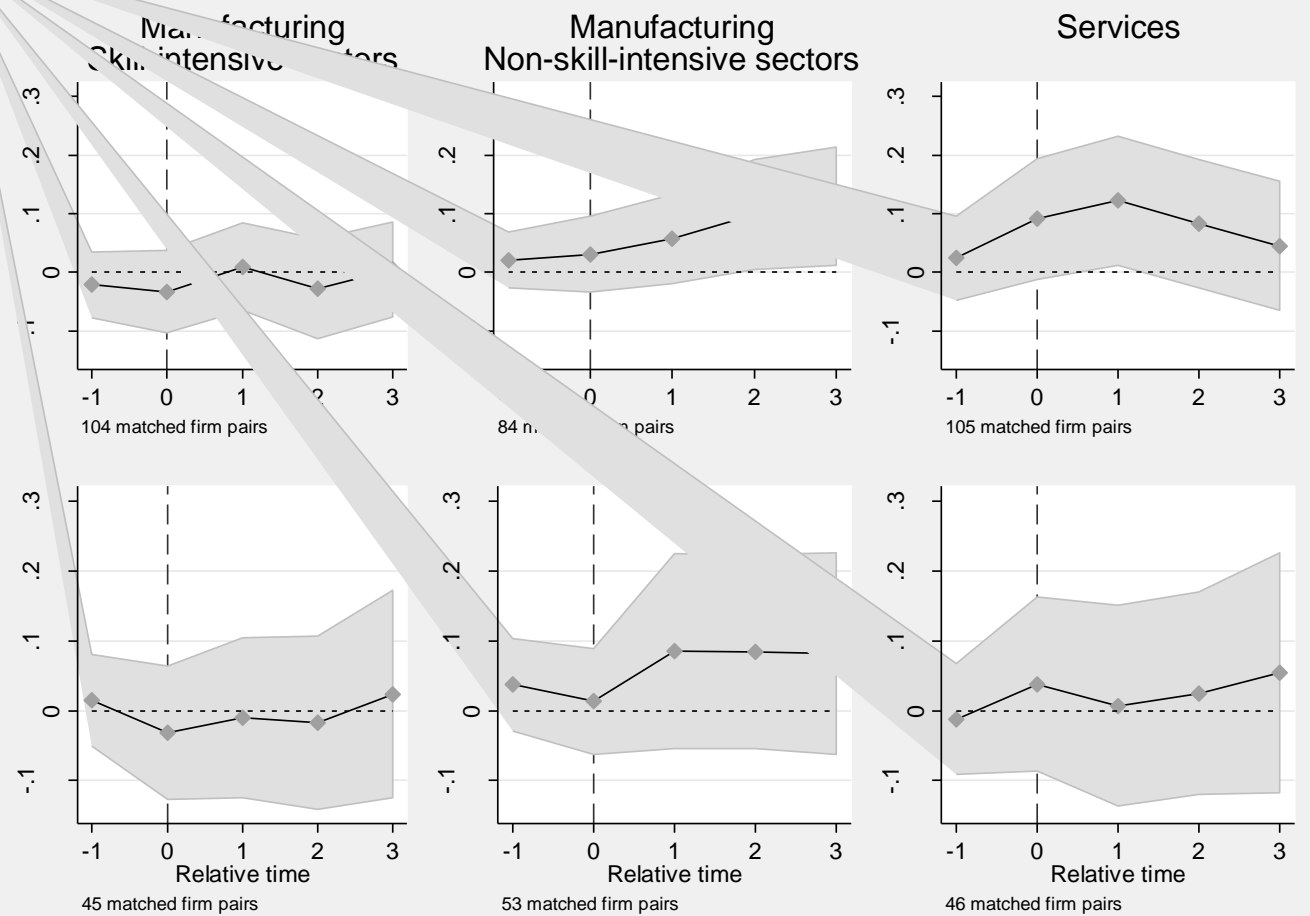
Notes: As in Figure 2. See Appendix 1 for details on TFP measurement.

\section{Concluding Remarks}

While anecdotal evidence of jobs displacement abounds, our systematic analysis of French manufacturing and services investment abroad over the period 1987-1999 shows that initiating production abroad is not detrimental to the parent firm's domestic employment. This confirms previous results in the literature, in particular those found by Barba Navaretti et al. (2010) for French manufacturing firms.

The first key contribution of our analysis is to show that the consequences of initiating production abroad for parent firms in manufacturing depend on the underlying investment strategy, which, in turn, can be related to the sector of origin and the income level of the recipient country.

- Investments in high-income countries by manufacturing firms in skill-intensive sectors mainly reflect horizontal, market-seeking motives. They have a significant positive impact on domestic employment in the parent firm compared to the counterfactual outcome of not investing abroad. No discernible impact is found on exports, TFP or the input mix, consistent with the prior that this type of investment does not significantly change the way the production process is organised in the parent firm.

- Investments in low-income countries by manufacturing firms in non-skillintensive sectors reflect vertical, factor-seeking motives. Vertical investment strategies pave the way for an international division of labour across the firm's production units. This has a strong positive impact on parent exports, and not surprisingly, has important implications for the way the production process is organised in the parent firm. Vertical FDI increases the capital-labour ratio (and possibly skill-intensity) and may also yield positive efficiency gains. However, in contrast to conventional wisdom, they do not translate into job losses in the parent firm. If anything, a positive impact is found on employment in the investing firm (these estimates are not statistically significant). On the whole, vertical FDI appears to be an efficient strategy to withstand competitive 
pressures. Despite relocating part of the production process abroad, employment gains are being registered on the segments that are retained at home.

- We classify as complex those FDIs that do not correspond to any of those two polar cases, and the results found in these cases are indeed a mix of those obtained for the pure strategies.

The second main contribution of this paper is to extend the analysis to the services sector. This is important for two reasons. First, FDI in services is very important in magnitude. In the most recent year of our sample, the number of first-time investors abroad in the services sector exceeded that in manufacturing. Second, our understanding of the growing internationalisation of the services sector is still very limited. The manufacturing-based typology referred to above cannot be straightforwardly applied to services. We find that services FDI is associated with strongly increased employment in the parent firm, by almost $20 \%$ (the same order of magnitude as that for horizontal FDI by manufacturing firms). Services FDI also appears to lead to lower capital-labour ratios in the parent firm. This may reflect new management and co-ordination needs arising from production complementarities between the parent firm and its affiliates. As for vertical FDI in manufacturing, services FDI is associated with a strong positive impact on the parent exports.

The present firm-level analysis allows one to provide a detailed picture of the effects of initiating production abroad in the parent firm after controlling for a rich set of observed and unobserved characteristics. However, such an analysis is also necessarily partial in nature as it does not account for potentially important general equilibrium effects. Another limitation worth recalling is that we focus on firms investing abroad for the first time. This is useful from an empirical perspective as it improves the identification of the impact of FDI, but it may also affect the generality of our results, particularly when the impact of first-time investment on the parent firm is very different from that of foreign investments by MNEs. In this sense, the focused approach followed here should be considered as complementary to other analyses of the domestic impact of foreign investment. 


\section{Acknowledgements}

We like to thank Richard Upward for very helpful comments and suggestions on an earlier draft as well as an anonymous referee and participants of the ISIT Conference in Stockholm, the COMPPRESS workshop in Budapest and seminar participants in Nottingham and Paris. The opinions expressed in this paper are those of the authors and do not necessarily reflect those of the OECD or its member states. All remaining errors are our own.

\section{References}

Amiti, M., \& Wei, S.-J. (2005). Fear of service outsourcing; Is it justified? Economic Policy 20, 308-347.

Amiti, M., \& Wei, S.-J. (2008). Does service offshoring lead to job losses? in M. Reinsdorf \& M. Slaughter (Eds.). International Flows of Invisibles (pp. 227246), Chicago: The University of Chicago Press.

Amiti, M., \& Wei, S.-J. (2009). Service offshoring and productivity: Evidence from the US. The World Economy 32(2). 203-220.

Arnold, J.M., \& Javorcik, B. (2009). Gifted kids or pushy parents? Foreign acquisitions and plant performance in Indonesia. Journal of International Economics 79(1), 42-53.

Barba Navaretti, G., \& Castellani, D. (2003). Investments abroad and performance at home. CEPR Discussion Paper 4284.

Barba Navaretti, G., Castellani, D. \& Disdier, A.-C. (2010). How does investing in cheap labour countries affect performance at home? Oxford Economic Papers, 62(2): 234-260.

Becker, S. O., \& Mündler, M.-A. (2008). The effect of FDI on job security. The B.E. Journal of Economic Analysis and Policy 8(1), article 8.

Bender, S., \& Von Wachter, T. (2006). In the right place at the wrong time: The role of firms and luck in young workers' careers. American Economic Review 96 (5), 1679-1705.

Bernard, A., Jensen, J., Redding, S. \& Schott, P. (2007). Firms in international trade. The Journal of Economic Perspectives 21(3), 105-130.

Blinder, A. (2006). Offshoring: The next industrial revolution. Foreign Affairs 85 (2), $113-128$

Blonigen, B. A., \& Wang, M. G. (2005). Inappropriate pooling of wealthy and poor countries in empirical FDI studies, in Theodore H. Moran; Edward M. Graham \& Magnus Blomstrom (Eds.), Does Foreign Direct Investment Promote 
Development?(pp. 221-244), Washington D.C.: Institute for International Economics, Center for Global Development.

Blundell, R., \& Costa Dias, M. (2002). Alternative approaches to evaluation in empirical microeconomics. IFS CEMMAP Working Papers CWP10/02.

Blundell, R., Dearden, L. , \& Sianesi, B. (2005). Evaluating the effect of education on earnings: models, methods and results from the National Child Development Survey. Journal of the Royal Statistical Society: Series A 168 (3), 473-512.

Blundell, R., Costa Dias, M., Meghir, C., \& Van Reenen, J. (2004). Evaluating the employment impact of a mandatory job search program. Journal of the European Economic Association 2(4), 569-606.

Clerides, S.K., Lach, S., \& Tybout, J.R. (1998). Is learning by exporting important? Micro-dynamic evidence from Columbia, Mexico, and Morocco. Quarterly Journal of Economics 113(3), 903-948.

Crinò, R. (2010). Service offshoring and white-collar employment. Review of Economic Studies 77(2). 595-632.

Debaere, P., Lee, H. \& Lee, J. (2010). Does where you go matter? The impact of outward foreign direct investment on multinationals' employment at home. Journal of Development Economics 91(2), 301-309.

Egger, P., \& Pfaffermayr, M. (2003). The counterfactual to investing abroad: an endogenous treatment approach of foreign affiliate activity. University of Innsbruck Working Paper 2003/02.

Ekholm, K., \& Hakkala, K. (2005). The effect of offshoring on labor demand: Evidence from Sweden. Research Institute of Industrial Economics Working Paper 654.

Feenstra, R. C. \& Hanson, G. H. (1999). The impact of outsourcing and hightechnology capital on wages: Estimates for the United States, 1979-1990," Quarterly Journal of Economics 114 (3), 907-940.

Francois, J., \& Hoekman, B. (2010). 'Services trade and policy. Journal of Economic Literature 48(3), 642-692.

Girma, S., \& Görg, H. (2007). Evaluating the foreign ownership wage premium using a difference-in-differences matching approach. Journal of International Economics 72(1), 97-112.

Girma, S., Greenaway, D., \& Kneller, R. (2004). Does exporting lead to better performance: A microeconometric analysis of matched firms. Review of International Economics 12 (5), 855-866.

Hahn, J. (1998). On the role of the propensity score in efficient semiparametric estimation of average treatment effects. Econometrica 66, 315-331.

Harrison, A. E., McMillan, M. S., \& Null, C. (2007). U.S. multinational activity abroad and U.S. Jobs: Substitutes or complements? Industrial Relations 46(19), 347365.

Head, K., \& Ries, J. (2002). Offshore production and skill upgrading by Japanese manufacturing firms," Journal of International Economics 58(1), 81-105. 
Heckman, J., Ichimura, H., \& Todd, P. (1997). Matching as an econometric estimator: Evidence from evaluating a job training programme. Review of Economic Studies 64 (4), 605-654.

Helpman, E., Melitz, M. \& Yeaple, S. (2004). Exports vs. FDI with heterogeneous firms," American Economic Review 94(1), 300-316.

Hijzen, A., Görg, H., \& Hine, R.C. (2005) "International outsourcing and the skill structure of labor demand in the United Kingdom. Economic Journal 115(506), 860-878.

Hijzen, A., Inui, T. \& Todo, Y. (2007). The effects of multinational production on domestic performance: Evidence from Japanese firms. RIETI Discussion Paper 07006.

Jacobson, L.S., LaLonde, R.L. \& Sullivan, D.G. (1993). Earnings losses of displaced workers. American Economic Review 83(4), 685-709.

Kleinert, J., \& Toubal F. (2007). The impact of locating production abroad on activities at home: Evidence from German firm-level data. Discussion Paper 314. University of Tubingen.

Klette, T.J. (1999), "Market Power, Economies of Scale and Productivity: Estimates from a Panel of Establishment Data", Journal of Industrial Economics 47, 451476.

Kolstad, I., \& Villanger, E. (2008). 'Determinants of foreign direct investment in services. European Journal of Political Economy 24(2). 518-533.

Lechner, M. (2001). Identification and estimation of causal effects of multiple treatments under the conditional independence assumption. in M. Lechner \& F. Pfeiffer (Eds.). Econometric Evaluation of Labour Market Policies, Heidelberg: Physica, 43-58.

Mankiw, N. G., \& Swagel, P. (2006). The politics and economics of offshore outsourcing. Journal of Monetary Economics 53(5). 1027-1056.

Markusen, J. R. (1984). Multinationals, multi-plant economies, and the gains from trade. Journal of International Economics 16(3-4). 205-226.

Markusen, J. R., \& Maskus, K. E. (2001). General-equilibrium approaches to the multinational firm: A review of theory and evidence. NBER Working Paper 8334.

Mélitz, M. J. (2003). 'The impact of trade on intra-industry reallocations and aggregate industry productivity. Econometrica 71 (6), 1695-1725.

Munch, J.R., \& Skaksen, J.R. ( 2009). Specialisation, outsourcing, and wages. Review of World Economics/Weltwirtschaftliches Archiv 145 (1), 57-74.

Mündler M.-A., \& Becker, S.O. (2010). Margins of multinational labor substitution. American Economic Review 100(5), 1999-2030.

Rosenbaum, P., \& Rubin, D. (1983). The central role of the propensity score in observational studies for causal effects. Biometrika 70, 41-55.

Rosenbaum, P. \& Rubin, D. (1985). Constructing a control group using multivariate matched sampling methods that incorporate the propensity score. The American Statistician 39(1), 33-38. 
Sianesi, B. (2004). An evaluation of the swedish system of active labor market programs in the 1990s. Review of Economics and Statistics 86(1), 133-155.

Slaughter, M. J. (2000). Production transfer within multinational enterprises and american wages," Journal of International Economics 50(2), 449-472.

Yeaple, S. (2003). The complex integration strategies of multinational firms and crosscountry dependencies in the structure of foreign direct investment" Journal of International Economics 60(2), 293-314. 


\section{APPENDIX 1}

\section{A Measuring TFP}

In order to measure TFP we apply the mean value theorem as suggested by Klette (1999). In practice this means that we transform the data in differences from the industry median within each year. There are two advantages to this transformation: i) it increases the flexibility to deal with firm heterogeneity within the industry; ii) it removes the need to use industry-level price deflators which are difficult to obtain for services. After transforming the data we estimate TFP as the residual of a CobbDouglas production function of capital, labour and materials. The production function controls for the possible correlation between input-choice and time-invariant productivity shocks by including individual-specific fixed effects.

\section{B Data Management}

In order to follow individual firms through time we organise the data around cohorts. Cohorts are defined as six-year windows around year $t[t-2 ; t+3]$ in which domestic firms establish a foreign presence. We impose the condition that within a six-year window the panel should be balanced. After having defined the cohorts we stack them together in order to create a 'panel of cohorts' running from 1988-1998 for manufacturing. Bender and Von Wachter (2006) observe that this effectively gives a system of seemingly unrelated regressions with cross-equation restrictions. 


\section{APPENDIX 2: Additional results}

Table A1: Breakdown of matched firm pairs by sector

\section{Panel A: Manufacturing}

17. Textiles

18. Wearing apparel

19. Leather and related products

20. Wood and of products of wood and cork

21. Paper and paper products

22. Printing and reproduction of recorded media

24. Chemicals and chemical products

25. Rubber and plastic products

26. Other non-metallic mineral products

27. Manufacture of basic metals

28. Fabricated metal products, except machinery

29. Machinery and equipment n.e.c.

31. Manufacture of electrical equipment

32. Radio, television and communication equipment

33. Precision instruments, optical

34. Motor vehicles, trailers and semi-trailers

35. Other transport materials

36. Furnitures

Other

\begin{tabular}{crrrr}
\multicolumn{2}{c}{ Low-income location } & & \multicolumn{2}{c}{ High-income location } \\
Non-skill- & Skill- & & Non-skill- & Skill- \\
intensive & instensive & & intensive & instensive
\end{tabular}

Total

$\begin{array}{rrrrr}5 & 0 & 8 & 0 & 13 \\ 10 & 1 & 11 & 0 & 22 \\ 2 & 0 & 3 & 1 & 6 \\ 2 & 0 & 2 & 1 & 5 \\ 1 & 1 & 4 & 2 & 8 \\ 0 & 1 & 1 & 8 & 10 \\ 0 & 14 & 0 & 32 & 46 \\ 10 & 0 & 7 & 0 & 17 \\ 2 & 1 & 7 & 5 & 15 \\ 3 & 2 & 2 & 3 & 10 \\ 4 & 2 & 14 & 6 & 26 \\ 1 & 5 & 1 & 18 & 25 \\ 1 & 2 & 6 & 7 & 16 \\ 0 & 4 & 2 & 3 & 9 \\ 6 & 5 & 3 & 8 & 22 \\ 2 & 0 & 2 & 2 & 6 \\ 0 & 1 & 2 & 3 & 6 \\ 3 & 3 & 8 & 0 & 14 \\ 1 & 3 & 1 & 5 & 10 \\ & & & & \\ 53 & 45 & 84 & 104 & 286\end{array}$

Panel B: Services

Sector

55. Hotels and restaurants

63. Auxiliary transportation services

70. Real estate

71. Rentals

72. Computing services

74. Business services

90. Waste management

92. Recreational activities

Other

\begin{tabular}{rrr}
\multicolumn{3}{c}{ Investment location } \\
$\begin{array}{r}\text { High- } \\
\text { income }\end{array}$ & $\begin{array}{r}\text { Low- } \\
\text { income }\end{array}$ & Total \\
8 & 2 & 10 \\
3 & 1 & 4 \\
5 & 0 & 5 \\
4 & 0 & 4 \\
15 & 3 & 18 \\
63 & 33 & 96 \\
3 & 5 & 8 \\
4 & 1 & 5 \\
0 & 1 & 1 \\
105 & 46 & 151
\end{tabular}

Note: Number of matched firm pairs by NAF 2-digit category in service sectors. The matching and the classification of sectors by skill intensity in manufacturing is carried out using a more detailed classification, hence the presence of investment classified as skill- and non-skill-intensive within the same sector. 
Table A2:

Balancing Tests for Multiple Treatment Matching

$\frac{\text { Unmatched }}{p<0.1 \quad p<0.05} \quad \frac{\text { Matched }}{p<0.1 \quad p<0.05}$

Manufacturing (out of 176 comparisons)

$\begin{array}{lcccc}\text { Investors to high-income locations } & 126 & 120 & 15 & 8 \\ \text { Investors to low-income locations } & 106 & 95 & 17 & 9 \\ \text { All } & 133 & 127 & 7 & 5\end{array}$

\section{Services (out of 190 comparisons)}

$\begin{array}{lcccc}\text { Investors to high-income locations } & 116 & 106 & 16 & 6 \\ \text { Investors to low-income locations } & 65 & 57 & 8 & 1 \\ \text { All } & 121 & 110 & 15 & 9\end{array}$

Note: The table shows the number of cases where the $p$-value of a $t$-test for equality of means between treated and non-treated firms is smaller than the indicated significance level. The comparison is carried out for each variable used in estimating the propensity scores (except squared log VA, i.e. 11 variables in manufacturing, 10 in services), separately for each sector (16 in manufacturing, 19 in services), hence 11 x $16=176$ comparisons in manufacturing, 10 x 19=190 in services.

Table A3: Semi-parametric estimates of the impact of FDI on employment

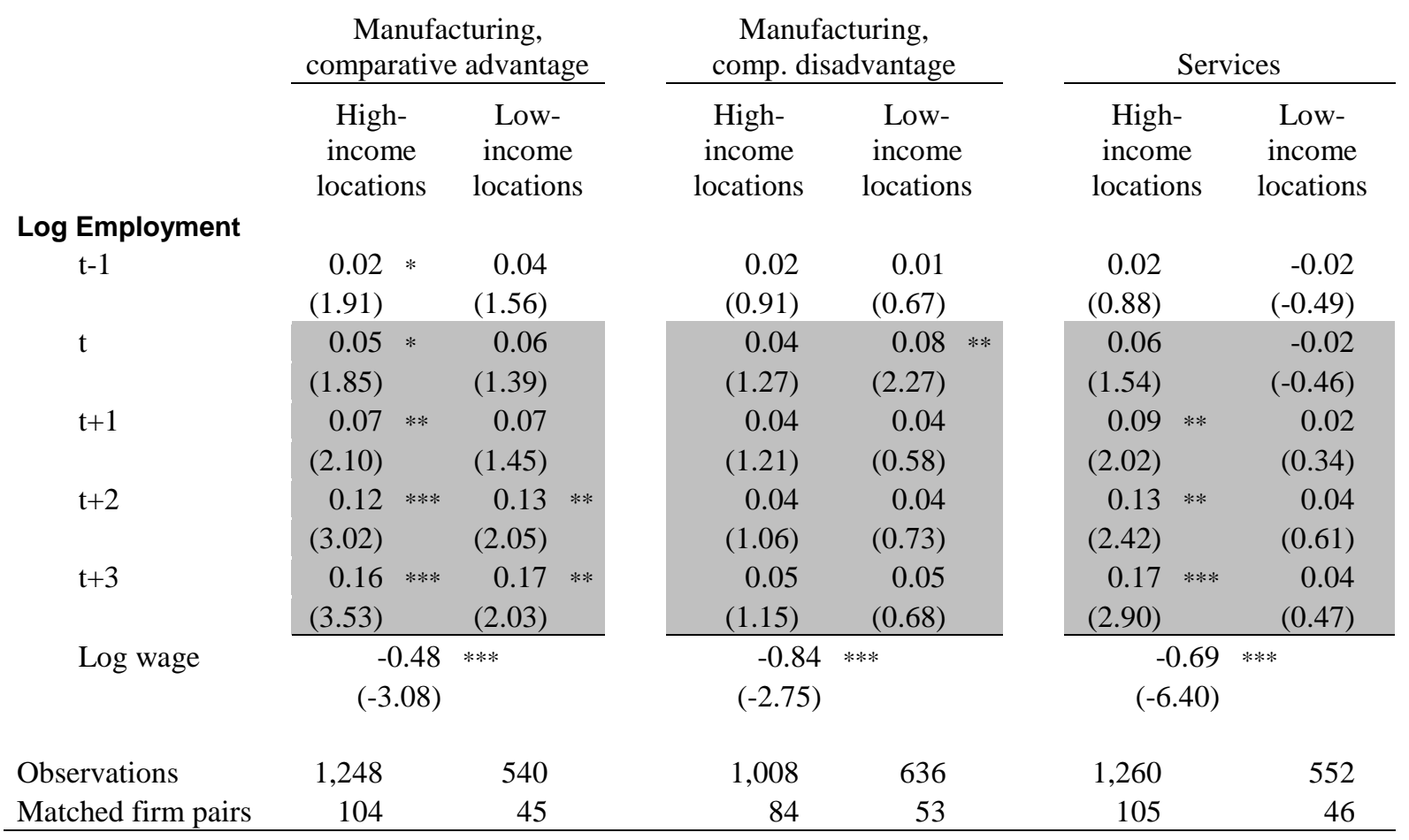

Note: The dependant variable is the change in the difference between switchers (i.e., first-time foreign investors) and the matched control group, based on means relative to the year for which the firms have been matched ( $\mathrm{t}-2$, where $\mathrm{t}$ refers to the year of investment). Bootstrapped standard errors in parentheses. $*, * *, * * *$ indicate statistically significance at $10 \%, 5 \%$ and $1 \%$ respectively. Standard errors are clustered 
around individual firms. All regressions include a constant, dummies for relative time and log average monthly wage (measured at the firm level).

\section{Appendix Table 4: Semi-parametric estimates of the impact of FDI on TFP}

\begin{tabular}{|c|c|c|c|c|c|c|}
\hline & \multicolumn{2}{|c|}{$\begin{array}{c}\text { Manufacturing, } \\
\text { comparative advantage }\end{array}$} & \multicolumn{2}{|c|}{$\begin{array}{l}\text { Manufacturing, } \\
\text { comp. disadvantage }\end{array}$} & \multicolumn{2}{|c|}{ Services } \\
\hline & $\begin{array}{l}\text { High- } \\
\text { income } \\
\text { locations }\end{array}$ & $\begin{array}{l}\text { Low- } \\
\text { income } \\
\text { locations }\end{array}$ & $\begin{array}{l}\text { High- } \\
\text { income } \\
\text { locations }\end{array}$ & $\begin{array}{l}\text { Low- } \\
\text { income } \\
\text { locations }\end{array}$ & $\begin{array}{l}\text { High- } \\
\text { income } \\
\text { locations }\end{array}$ & $\begin{array}{l}\text { Low- } \\
\text { income } \\
\text { locations }\end{array}$ \\
\hline \multicolumn{7}{|c|}{ Total Factor Productivity } \\
\hline \multirow[t]{2}{*}{$\mathrm{t}-1$} & -0.03 & 0.00 & 0.02 & 0.02 & 0.02 & -0.02 \\
\hline & $(-1.24)$ & $(-0.01)$ & $(1.03)$ & $(0.77)$ & $(0.60)$ & $(-0.49)$ \\
\hline \multirow[t]{2}{*}{$\mathrm{t}$} & -0.05 & -0.05 & 0.02 & -0.02 & 0.07 & 0.012 \\
\hline & $(-1.53)$ & $(-1.28)$ & $(0.66)$ & $(-0.86)$ & $(1.61)$ & $(0.22)$ \\
\hline \multirow[t]{2}{*}{$\mathrm{t}+1$} & -0.02 & -0.05 & 0.03 & 0.04 & $0.10 * *$ & -0.02 \\
\hline & $(-0.64)$ & $(-1.01)$ & $(0.91)$ & $(0.68)$ & $(2.11)$ & $(-0.29)$ \\
\hline \multirow[t]{2}{*}{$\mathrm{t}+2$} & $-0.07 * *$ & -0.08 & 0.05 & 0.05 & 0.06 & 0.01 \\
\hline & $(-2.08)$ & $(-1.38)$ & $(1.22)$ & $(0.74)$ & $(1.27)$ & $(0.14)$ \\
\hline \multirow[t]{2}{*}{$t+3$} & $-0.07 *$ & -0.06 & 0.05 & 0.02 & 0.01 & 0.04 \\
\hline & $(-1.69)$ & $(-1.14)$ & $(1.24)$ & $(0.30)$ & $(0.27)$ & $(0.52)$ \\
\hline Log turnover & \multicolumn{2}{|l|}{$\begin{array}{r}0.48 \\
(13.77)\end{array}$} & \multicolumn{2}{|c|}{$\begin{array}{r}0.53 \\
(8.57)\end{array}$} & \multicolumn{2}{|l|}{$\begin{array}{r}0.23 \\
(5.04)\end{array}$} \\
\hline \multirow{2}{*}{$\begin{array}{l}\text { Observations } \\
\text { Matched firm } \\
\text { pairs }\end{array}$} & 1,248 & 540 & 1,008 & 636 & 1,236 & 552 \\
\hline & 104 & 45 & 84 & 53 & 103 & 46 \\
\hline
\end{tabular}

Note: The dependant variable is the change in the difference between switchers (i.e., first-time foreign investors) and the matched control group, based on means relative to the year for which the firms have been matched ( $\mathrm{t}-2$, where $\mathrm{t}$ refers to the year of investment). Bootstrapped standard errors in parentheses. $*, * *, * * *$ indicate statistically significance at $10 \%, 5 \%$ and $1 \%$ respectively. Standard errors are clustered around individual firms. All regressions include a constant, dummies for relative time and log turnover. 
Figure A1: Impact of Foreign Investment on Skill-Intensity, by Income Level of the Recipient

\section{Country and by Sector}

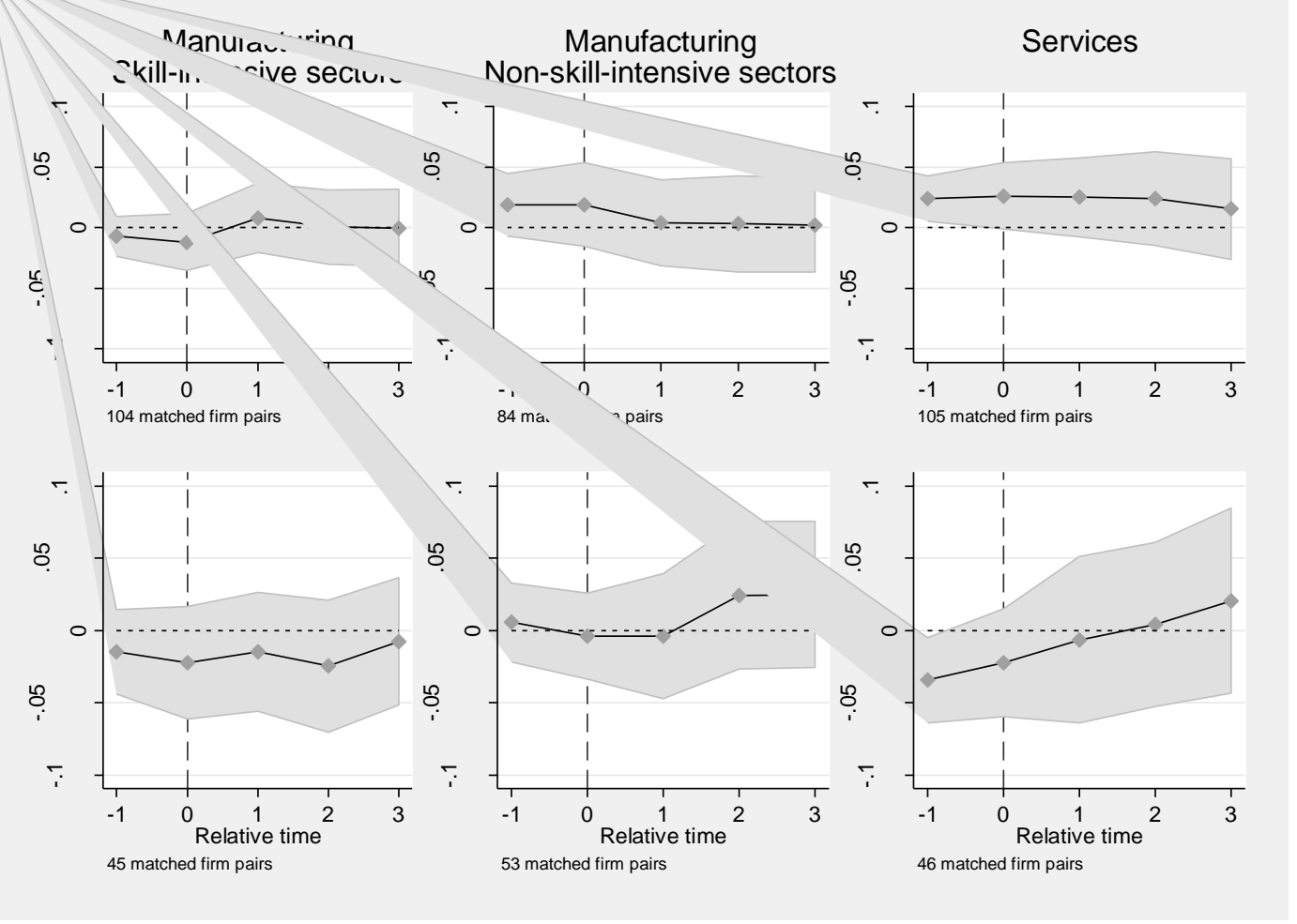

Notes: As in Figure 2. Average labour skill is measured as the average yearly wage in the firm. 